\title{
Rituals of Critique and Institutional Maintenance at the United Nations Climate Change Summits
}

Gazi Islam

Professor of Business Administration

Grenoble Ecole de Management, Univ Grenoble Alpes ComUE

IREGE, Université Savoie Mont Blanc

Email: gazi.islam@grenoble-em.com

Charles-Clemens Rüling

Professor of Organization and Management Theory

Grenoble Ecole de Management, Univ Grenoble Alpes ComUE

IREGE, Université Savoie Mont Blanc

Email: charles-clemens.ruling@grenoble-em.com

Elke Schüßler

Professor of Business Administration and Head of Institute of Organization Science Johannes Kepler University Linz

Email: elke.schuessler@jku.at

Final published paper can be found here:

https://www.emerald.com/insight/content/doi/10.1108/S0733-558X2019000065B004/full/html

All authors have contributed equally to this chapter. Author names are therefore in alphabetical order. 


\begin{abstract}
Particularly in governance and policy processes, critique is embedded in highly institutionalized formats. In this paper we apply Boltanski's concept of critical tests to examine accepted forms of expression in the context of an institutionalized policy setting, the annual Conferences of the Parties to the United Nations Framework Convention on Climate Change (UNFCCC). We find that different policy actors' uses of critique reflect embedded field positions and interests. While marginal actors drew upon existential tests to construct radical critique, the highly ritualized performance of critique called into question its efficacy in promoting change within the overall structure of a highly institutionalized event. We discuss inroads to studying the relations between critique, power, and microfoundations of institutions.
\end{abstract}

Keywords: ritual, critique, institutional work, institutional change

\title{
Postscript
}

By the time this volume comes into production, the Fridays for the Future school strikes, initiated by Greta Thunberg in the autumn of 2018, have developed into a strong international civil society movement that mobilizes students from around the world to fight climate change. Recent forms of climate mobilization, especially the Extinction Rebellion Movement, are eluding institutionalized arenas of transnational climate policy. In terms of our argument, they represent an ultimate form of a radical test that harnesses the power of human experience to expose the limitations of current policy frameworks.

\section{Acknowledgemenets}

The authors would like to acknowledge the support of Guido Möllering, Patrick Haack, Lee Jarvis, and Bilal Jathol, whose help in various stages of this work is greatly appreciated. 
It was believed that the seasons would not follow one another in due order unless the Emperor, the Son of Heaven, performed the established rites at the appropriate times. (Radcliffe-Brown, 1958, p. 158)

In December 2018, fifteen-year old Greta Thunberg captured global media headlines when she delivered a statement at the high-level plenary of the 24th Conference of the Parties to the United Nations Framework Convention on Climate Change (UNFCCC) in Katowice, Poland. Speaking on behalf of non-governmental organizations, she scolded representatives of more than 200 countries for their inability to address climate change, and for sacrificing civilisation "for the opportunity of a very small number of people to continue to make enormous amounts of money" (ENGO, COP 24, 2018). What the media did not address was the fact that radical critique by environmental and youth non-governmental organization during UNFCCC highlevel plenaries has been a constant feature of UN climate summits since the mid-1990s - yet did not help in reaching the UNFCCC's aims of reducing carbon emissions through effective, transnational policies (Schüßler, Rüling, \& Wittneben, 2014).

The role of organized events in institutional creation and maintenance is a topic of emerging scholarly interest in organizational theory (e.g. Anand \& Watson, 2004; Massa, Helms, Voronov, \& Wang 2016), not least because events provide unique opportunities for bridging micro and macro levels of institutional analysis (Lampel \& Meyer, 2008). Events provide moments in which institutional norms are collectively displayed and reproduced (Dacin, Munir \& Tracey, 2010; Zilber, 2011), where continuity with the past is reaffirmed in moments of crisis (Islam \& Keliher, 2017), and where institutions are embued with collective inspiration and affect (Massa et al., 2016). Yet, such moments also provide opportunities for institutional change attempts (Hardy \& Maguire, 2010), where marginal actors can reconstitute institutional boundaries (Patriotta \& Hirsh, 2016) and fields are restructured and innovated (Schüßler, Grahber \& Müller-Seitz, 2015). The maintenance and reaffirmation functions of collective events have been discussed in terms of ritual (Dacin et al, 2010), while the change potential of events is seen as a result of the openness of discursive spaces at so-called fieldconfiguring events (Lampel \& Meyer, 2008; Hardy \& Maguire, 2010). Yet, while current literature recognizes that organized events contribute to both institutional change and maintenance (Islam, 2015; Schüßler, Rüling, \& Wittneben, 2014), the micro-practices by which different actors enact maintenance and change attempts within such events remain less well understood.

One way to explore the enactment of of maintenance and change is to recognize how such practices of "institutional work" (Lawrence \& Suddaby, 2006) themselves depend on taken-for-granted background structures, and how these structures in turn are stabilized or challenged through "tests" that compare reality with institutional norms (Boltanski, 2011). Paraphrasing Turner (1969), the limits of order are often represented internally via cultural practices such as rituals, where norms are reaffirmed in the face of existential threat. Thus, structure and "anti-structure" are mutually necessary to constitute social orders (Turner, 1969). Institutional change presupposes norms against which change can occur (Boltanski, 2011), and maintenance requires ongoing discursive work to manage changing environmental contingencies and threats to order (Taupin, 2012). Drawing on Boltanski (2011), institutions require periodic realization in "embodiments" such as concrete practices and structures, but these embodiments leave gaps between the institutional ideal and its realization. In such moments, when inconsistencies between institutional norms (or "orders of worth" in conventionalist theory terminology) and micro-level agency become visible, actors may deploy various forms of tests with various degrees of intentionality and reflexivity regarding institutional maintenance or change (cf. Dansou \& Langley, 2012). 
In this paper, we use Boltanski's (2011) concept of critique to examine the different ways in which actors address discrepancies between institutional norms and agency in the context of climate change policy, in order to better understand dynamics of institutional maintenance and change in this highly contested field. Empirically, we examine the annual Conferences of the Parties (COPs) of the United Nations Framework Convention on Climate Change. In addition to actual technical negotiations, political actors at these annual events make formal, public statements to support or challenge positions and policies regarding climate change. Examining these statements as a form of institutional work, our key research question is "How do actors across the political spectrum use different forms of critique to change or maintain institutional orders within organized events?"

The rest of the paper will unfold as follows. We begin by discussing the role of critique in organized events, drawing upon Boltanski's (2011) discussion of critique to examine the relation between ritualized institutional affirmation and the articulation of institutional critique. Laying out our empirical study of the COPs at the UNFCCC, we argue that the heterogenity of forms of critique expressed by actors corresponded to actors' relative power positions in the climate change policy debate, where more powerful actors deployed less radical forms of critique, and less powerful actors used radical forms of critique to stress the need for a new institutional order. While this pattern in itself may not be surprising, it leads us to the proposition that the stability in the performance of different forms of critique undermined the change potential of reformist and radical forms of critique. The scripted nature of critique, particularly regarding radical critique by marginal actors, also suggests that the UNFCCC's attempt to give marginal actors a discursive platform did not ensure a robust and meaningful challenge to the dominant order. We expand on this point in the discussion to speculate on the role of critique as mere ritual versus the possibility of system-challenging radical critique.

\section{Organized Events as a Sites for Studying Institutional Critique}

Organized events are moments of the embodiment of the social. They are public performances of the collective bond (Boltanski, 2011; Islam 2015; Durkheim, 1961). As such, events constitute sites where different kinds of tests are deployed, as discrepancies between institutional orders and the realm of action become visible, embodied and possibly articulated. On the one hand, events affirm and reinforce the sense of social unity, an order-preserving function (Rojek, 2013). On the other hand, events are used to display moments of rupture and crisis (van Gennep, 1960), enacting society's faultlines and dramatizing the limits of social orders (Toraldo, Islam \& Mangia, 2018). In this aspect, events always contain a component of "anti-structure" (Turner, 1969), a moment of uncertainty that can be destabilizing. The ability of events to straddle the boundary of structure and anti-structure explain the power of ceremony across societies (Turner, 1969), and may explain why events are so often used as sites of institutional change attempts (e.g. Puett, 2006). This dual aspect of events, however, creates conceptual dilemmas as to how the reaffirmative and disruptive properties of events can be reconciled, and how the tensions between the two are worked out in practice.

In their ritualistic aspect, events are able to demonstrate and affirm the social unity through repetition of their norms; because institutions are "bodiless" (Boltanski, 2011), they require concrete embodiments or practices through which they can become real. From this perspective, events perform and demonstrate underlying institutions and in doing so, performatively make those institutions real. At the same time, events can be occasions to test reality against social norms, to judge practices and launch critique, but also to affirm and reproduce practices by displaying them as exemplars of an underlying institutional order. This difference between concrete examples and abstract ideals provides a basis for judgement and evaluation (Boltanski \& Thévenot, 2006). 
The notion of "testing" the realm of institutional norms against the reality of lived human experience draws upon a tradition of French pragmatist sociology (e.g. Boltanski \& Thévenot, 2006), a tradition recently recognized by organizational scholars as offering avenues into the microfoundations of institutions (Cloutier \& Langley, 2013; Brandl, Daudigeos, Edwards, \& Pernkopf-Konhäusner, 2014; Patriotta, Gond, \& Schultz, 2011). This perperspective "provides a situated, relational, and practice-oriented framework for studying how actors negotiate and justify actions through shared moral 'worlds' that are akin to institutional logics" (Boxenbaum, 2014: 319). Whereas French pragmatist sociology focuses on interactions among individuals largely "from the bottom up" (Bullinger, 2014), institutional theory operates from the "top down", thus resulting in the "paradox of embedded agency" (Battilana \& D'Aunno, 2009) that, in a sense, is at the heart of the microfoundational research agenda in new institutionalism.

Rather that framing the micro-macro divide as one paralleling the agency-structure dichotomy (e.g. Abdelnour, Hasselbladh, \& Kallinikos, 2011; Hodgson, 2007), Boltanski (2011) distinguishes "contexts" from "situations", with situations always being anchored in context, yet providing particular avenues for change and deviation from contexts through shifts in attention and unfolding dynamics of interaction (cf. Stones, 2014). As argued by Dansou and Langley (2012: 513): "In conventionalist theory, individuals are in no way attached to orders of worth; they 'can be acquainted with more than one world' (Boltanski \& Thévenot, 2006: 219), and have the ability to adjust their behavior in accordance with the situation they face." Following the call to use this tradition to "inspire debates on the micro-macro divide in the institutional community" (Brandl et al., 2014: 315), we focus on critical "tests" as described in French pragmatist sociology (Boltanski \& Thevenot, 2006; Boltanski \& Ciapello, 2005; Boltanski, 2011). Tests are "critical moments" in social life "when actors' performance of widely accepted established rules, norms and belief systems are questioned" (Dansou \& Langley, 2012: 509). As moments for the possibility of critique, tests involve judgements around the adequacy of the status quo vis-à-vis underlying criteria of worth. In On Critique, Boltanski (2011) elaborates different types of tests based on his distinction of "the world" (the realm of lived experience; everything that is in the background; cf. Blocker, 2014) and "the reality" (closed sets of meanings ascribed to reality; cf. the constructed - institutionalized social order). Since On Critique has an explicitly emancipatory agenda, tests are explored as both means of maintaining the constructed institutional order (the reality) and as possible means of disruption by confronting the reality with the world. Tests hereby provide a conceptual bridge between micro-processes and macro-institutional orders (cf. also Dansou \& Langley, 2012: $505)$.

Boltanski (2011: 94) argues that institutions should not be considered as "pure semantic systems" disembedded from material relations. Rather, institutions are embodied in concrete micro-practices such as rituals, although the concrete level of practices does not always cohere with the deeper institutional principles, or the core feelings of inclusion and membership that hold institutions together. These different layers exist in tension with the materiality of institutions "chained to the semantic and administrative systems which justify its existence". For Boltanski (2011), the embodiment in practice of institutions rests on the attempt to match a world of lived experience to a symbolic and rule-goverened order. Background experience forms a taken-for-granted support, which is leveraged to evaluate and "test" the embodied practices for their fidelity to that assumed ground.

Boltanski (2011) distinguishes three progressively more radical "tests" that compare (socially constructed) reality with the world of lived experience. "Truth tests" connect an instance of a practice with a rule or standard, to bring the practice in line with the standard and in the process legitimate the authority of the underlying standard. Truth tests are based on repetition, such as periodic ceremonies or rituals, and focus on stylized discourses, roles and 
behaviors. Their goals are at once to bring the reality into line with the norm and thus reproduce practices, but they also have a performative function, namely, "to make visible the fact that there is a norm, by deploying it in a sense for its own sake" (Boltanski, 2011: 104). Thus, the focus is on repetition and ritual, and the attempt to absorb deviant cases or "errors" into the fold of accepted practice. It is still a test, though, because material or technical failures of confirmation remain possible.

Whereas truth tests seek to reproduce a standard in the face of a varying and "messy" environment, "reality tests" challenge an accepted practice or standard by highlighting a mismatch between the established institutional order and the actual state of affairs. Reality tests thereby open up a space for reformist critique, allowing the correction of reality by changing material arrangements or policies. However, reality tests also do not question the "reality of the reality" (Boltanski, 2011, p. 107) as such. Such questioning only occurs through "existential tests" (Boltanski, 2011), which can become sources of radical critique of the constructed reality by opening "a path to the world" (p. 108). Existential tests often use highly emotive forms of expression, and evocative forms of communication such as aesthetic modalities and references to individual lived experience that represent "the world" rather than the reality. However, typically coming from the margins of an institutional order, these radical forms of critique are often dismissed as subjective, aberrant or abnormal.

Figure 1 illustrates the three types of tests in relation to the reality and the world. As visualized in Figure 1, truth tests affirm the social order and adjust practices to align to accepted norms, while reality tests acknowledge tensions, fissures or gaps within the social reality itself, allowing critique by comparing parts of reality or question inconsistencies between policies and underlying values. Finally, existential tests reveal the provisional nature of social reality, questioning the fundamental values of an order and reaffirming the ability of the social to reconstitute itself.

Insert Figure 1

Given this array of possible critical moves involving diverse tests, we still know little about how actors deploy critique in order to change, maintain or disrupt institutional orders. As noted above, events are moments in which different actors deploy institutional work from their respective positions, and it is possible that the forms of critical test used will reflect these underlying positions. In order to explore this possibility, we turn to our empirical case.

\section{Empirical Context and Method}

Transnational climate policy constitutes a contested domain of institutional change and maintenance, and the annual UN climate summits represents the principal policy arena in which maintenance and contestation of an established social order embodied in UN climate policy texts, instruments, and procedures unfold (Schüßler et al., 2014). These events are both public in the sense that they are the object of high media and observer scrutiny, highly institutionalized, unfolding each year according to a clearly defined protocol, strongly embedded into the overall normative space of transnational diplomatic exchanges and in the $\mathrm{UNFCCC}^{1}$ itself, functioning as "an important source of moral norms" (Moellendorf 2016: 104) by establishing climate change as a common concern, acknowledging the historical responsibility of developed

\footnotetext{
${ }^{1}$ For the full text of the Convention, see: https://unfccc.int/resource/docs/convkp/conveng.pdf
} 
countries for climate change, and by affirming that developing countries have a right to sustainable social and economic development.

Building on Boltanski's (2011) notion of types of tests, we empirically observe forms of critique in plenary statements made by representatives of governments and observer organizations during the high-level segments of the annual UNFCCC COPs. These plenary statements occur at particular moments within the overall event: in the context of the opening ceremony and after a first week of technical negotiations. The high-level plenaries involve a series of formal three-minute statements delivered by heads of state and governments, ministers, heads of national delegations and intergovernmental organizations, as well as by representatives of non-governmental observer groups affirming their agendas and priorities for climate policy. Regarded as critical signals for actors' positions, plenary statements are highly scrutinized among attendees and the media.

We consider COP plenary statements as an ideal site to study moments and forms of tests where the central assumptions, values, and instrumentscharacterizing the UNFCCC are both enacted and challenged, i.e. "put to a test" when state representatives and other actors justify their position in the climate negotiations (cf. Dansou \& Langley, 2012, who mention comparable formalized moments such as performance appraisal meetings in organizations as moments where "testing" occurs). Tests may also unfold in other formal and informal discursive spaces during the COPs, but high-level plenary sessions provide a particularly salient context for two reasons: First, they represent one of the most publicly exposed moments during the otherwise largely access-restricted COPs, bringing together states and non-governmental actors, and functioning as prime arenas for the display of tests to affect field-level positions on climate change. Second, in terms of research methods, they provide a setting that has remained largely unchanged since COP 1 held in Berlin in 1995 and therefore allow comparison not only across actors, but also over time.

In order to study forms of critique, we sought to focus on various types of actors holding distinct positions in the climate policy field including developed countries (so-called Annex 1 countries in the context of the UNFCCC), newly industrialized countries, and developing countries particularly exposed to the effects of climate change, as well as non-governmental organizations. We decided to include the United States and Germany as two of the major Annex 1 countries historically associated with high levels of emission of greenhouse gases, Brazil as a large newly industrialized country, and the Maldives and Tuvalu as two developing countries that are particularly exposed to rising sea levels. In terms of non-governmental organizations (NGOs), we chose to include environmental NGOs as well as as well as Youth organizations, which both figure among the most important formally recognized observer consituencies.

In order to capture changes over time, we collected high-level plenary statements over the course of ten COPs. While our focus was mainly on the time-period following the 2005 entry into force of the Kyoto Protocol (2006, 2008-2013, 2015), we also included two earlier COPs (1997 and 2001), seeking to include data for both high-stakes COPs, i.e. conferences that are perceided to play a critical role within multi-year negaotiation cycles and attract particular high media scrutiny, as well as lower-stakes COPs perceived as more routine events within the overall climate policy process (Schüßler et al., 2014).

We retrieved 66 plenary statements from the UNFCCC's electronic archive (not all selected governments and NGOs gave statements at all COPs covered) delivered between 1997 and 2015. For some events, we were able to collect the texts of the speeches, whereas for others, we transcribed statements from video recordings of the COP plenary sessions. Reflecting the strict time limitation to COP plenary statements, the statements collected had an average length of 760 words, ranging from a short 76-word ENGO statement in 2012 to a 1736-word plenary address by US president Obama at COP 21 (2015). 
We engaged in multiple rounds of coding using Atlas.ti to analyze the plenary statements, seeking to identify actors' claims and issues, and their connections to aspects of the institutional order embodied by the UNFCCC. In the first round of coding we focused on identifying themes related to climate change and climate policy in the statements - including descripting codes such as "carbon trading", "emission targets", "deforestation", "sustainable development", and "rising sea levels" -, as well as on the display of emotions such as "indignation", "despair", or "pride". To our surprise, we found that actors' statements systematically differed not just in terms of emotional tone adopted - with positive emotional displays more frequent used by industrialized countries -, but also in the themes and issues addressed. Statements from industrialized countries mainly concentrated on progress in the UNFCCC process and discussed policy instruments developed within the UN climate policy framework, whereas plenary statements delivered by developing countries and NGOs shared a tendency to more fundamentally question the UNFCCC. Building on these initial observations, we developed a more abstract coding scheme in order to analyze the COP plenary statements through the lens of Boltanski's (2011) three forms of test. In line with the theoretical ideas outlined above, we coded text passages addressing actors' alignment with UNFCCC principles as "truth tests", text passages that referred to issues of alignment of actions, policies, and instruments with the principles of the UN climate policy framework as "reality tests", and text passages that emphasized contradictions between the UN climate policy process and the world of lived human experience as "existential tests" (see Table 1 for illustrative quotes). Our findings and discussion section below build on an analysis of the three types of test in our data across actors and over time.

Insert Table 1

\section{Findings}

The variety of types of test present in the COP high-level plenary statements reflect the paradoxical nature of field-level organized events combining elements of ritual and reaffirmation of established order with radical critique and attempts to disrupt established positions and beliefs. Our data include instances of delegates' practicing all three forms of critique (and their combination); yet, we also found that the three types of tests were not used in the same ways across actors. Most notably, our analysis found a clear divide between large, industrialized countries on the one hand, and poorer countries among the most exposed to the consequences of climate change, on the other. NGOs in our sample were close to countries highly exposed to climate change, with Youth NGOs most strongly engaging in radical critique. In the following sections, we first illustrate instances of Boltanski's (2011) three forms of critique, then explore the differences in patterns across actors, and finally examine the stability of forms of critique over time.

\section{Forms of Critique in UN Climate Policy}

The plenary addresses at the UN climate embody all of Boltanski's (2011) types of tests as communicative practices directed at institutional reproduction and change. Truth tests aim at sustaining the "reality of reality" by affirming the alignment of practices with central values and instruments of social reality. Truth tests in the COP plenary addresses occurred in two distinct forms: In their first form, truth tests affirm collective accomplishments in full alignment with the objectives and the values of the UN climate policy process. The following 2012 USA 
plenary statement, for example, centers on collective progress in the implementation of previous decisions:

The work to date has been very important. ... we have made substantial progress over the past three years. We have recorded mitigation pledges by over 80 countries and written new transparency guidelines; we have met our fast start financing commitment, and established a Green Climate Fund and a new Standing Committee; we created a Technology Executive Committee and a Technology Center and Network; and we set up an Adaptation Committee. (USA, COP 18, 2012)

The second form of truth tests in the plenary confirm actors' alignment with the values and principles underlying the UNFCCC by affirming continued commitment and contribution to climate change mitigation. In the following statements, the representative of Germany (2011) emphasizes developed country support for climate change mitigation in the developing world, and the Brazilian government (2012) highlights its national mitigation efforts:

The German government is delivering on its promises; its pledges for additional financing ... have already been implemented ... and will be fully met by the end of 2012. ... These funds support mitigation and adaptation in about 100 developing countries. (Germany, COP 17, 2011)

Brazil's national voluntary commitment to mitigate climate change is reflected through the country's consistent reduction of emissions from land use and forestry. It is also reflected in the creation and enactment of its National Policy on Climate Change... (Brazil, COP 18, 2012)

Reformist critique, embodied in reality tests, also contributes to institutional maintenance; yet, it does so by shedding light on contradictions within the prevalent social order. In our data, reality tests mainly concerned policy inconsistencies and implementation problems. Our data comprised two kinds of reality tests hinted at by Boltanski (2011). First, reality tests can question ways in which the social orders' central values materialize in reality, as for example in the following statement by the representative of Brazil in 1997, which displays critique of a lack of implementation on the side of Annex 1 countries, without, however, questioning the notion of "global partnership" that underlies developing country commitments:

Five years ago, Brazil hosted the United Nation's Conference on Environmental Development. A global partnership ensued there. A partnership with common but differentiated responsibilities. But today the convention implementation by the developed countries' commitments has been nothing less than disappointment. (Brazil, COP 03, 1997)

The second kind of reality tests we observed in the COP plenary addresses emphasize inconsistencies between various logics co-existing within the social reality of climate policy. The following passage from Brazil's (2009) plenary statement, for example, emphasizes tensions between climate change mitigation and the economic development of lessindustrialized economies, and between accountability for international funding and the sovereignety of receiving states:

For the developed world, three meals is something ... they achieved a long time ago, but for Africa, for Latin America and for many Asian countries this is something still 
for the future ... [I]t is not only ... the climate change issue that we are discussing, we have to discuss development and opportunities for all countries. ... [T] hose countries that will contribute with funds, they have the right to demand for transparency, they do have the right even to demand compliance of the policy that was financed, but it is also true that we need to be very careful with this intrusion or intervention into the developing countries... (Brazil, COP 15, 2009)

Other than truth and reality tests, which operate within the confines of established social order, the third form, radical critique, taking the form of existential tests, opens social reality to the "world" of uncertain, lived human experience and aims at unmasking the incompleteness and contingency of social reality and its institutionalized order. COP plenary addresses in our sample made use of existential tests in two ways: In their first form, existential tests contrast the values underlying the UNFCCC process with actual physical experience and fear for existence, such as in the following examples drawn from plenary addreses delivered by representatives of the Maldives (2011) and of Tuvalu (2015), which both emphasize the threat to collective survival based on countries' growing experience of adverse climate effects:

We cannot be asked to compromise when our survival as a nation is at stake. Every concession we make is a physical concession rather than just a political one, because we concede our land and livelihoods to the worsening climate impacts. (Maldives, COP 17, 2011)

Our survival as a nation depends on the decisions we take at this Conference. This is not simply a stepping-stone to a better future. We stand on a cliff edge. Either we stand united and agree to combat climate change or we all stumble and fall and condemn humanity to a tragic failure. (Tuvalu, COP 21, 2015)

A second form of existential test predominantly used by NGOs sets out to challenge the mandate and the actions of government delegates by emphasizing NGOs' strong civil society mandate and highlighting government representatives' personal responsibility for determining the future of humankind. The following Youth NGO statements (2006 and 2011) emphasize endorsement outside the institutional realm of the UNFCC, and appeal to negociators' sense of self and responsibility beyond institutional roles:

We have been mandated by thousands, millions of youth all over the world. ... Forget all political and economic agendas and simply visualize the kind of world that you would truthfully want for your children. What do you see? Now go ahead, create it. The power is in your hands right now right here. (Youth, COP 12, 2006)

I am speaking for more than half the world's population. We are the silent majority. You've given us a seat in this hall, but our interests are not on the table. ... You have been negotiating all of my life. In that time, you've failed to meet pledges, you've missed targets, and you've broken promises. (Youth, COP 17, 2011)

\section{Critique and Actor Positions over Time}

Our illustrations for the three types of tests above suggest that forms of critique differ across actors. Figure 2 shows these differences by displaying the prevalence of forms of critique in the COP plenary addresses. As we will show below, these patterns of critique have remained relatively stable over time. 
Insert Figure 2

Truth tests, aiming at the affirmation of established order, dominated for the USA and Germany, and for Brazil. On the contrary, existential tests embodying radical critique only played a marginal role in their plenary addresses. Speeches delivered by US Vice-president Al Gore (1997) and President Barack Obama (2015) were the two only US addresses in our sample that included existential tests. The USA, Germany, and Brazil also had the lowest relative share of reality tests among the seven actors included in our study. Taken together, these observations suggest that economically powerful actors, especially largest historical emitters of greenhouse gases tended to engage in affirming and stabilizing the institutional order underlying UN climate policy.

On the opposite side less economically powerful actors and probably victims of climate change - in our case two small island states as well as the two non-governmental observer groups - more strongly engaged in both reformist and radical forms of critique. Statements by the Maldives and by Tuvalu, as well as by environmental NGOs were characterized by the dominance of reality tests together with a share of existential tests eight to ten times higher than for Brazil and Germany. On the extreme side, statements by Youth NGOs were marked by the dominance of existential tests and a complete absence of truth tests, which reflects Youth NGO's position as non-expert "outsiders" in the UN climate policy field.

Actor-specific patterns of critique remained relatively stable over time. Figure 3 shows the number of text passages in the plenary statements that were associated with the three test types for the UN climate summits between 1997 and 2015 covered by our study. Considering the evolutions of the overall climate policy process as well as country-level political changes, overall actor-level patterns over time seemed surprisingly stable. With the exception of speeches held by Gore and Obama in Kyoto (1997) and Paris (2015), no US address did contain any existential test, and only one out of the ten climate summit addresses by representatives of Germany and Brazil contained an instance of existential test. On the opposite side of the spectrum, reality tests were constantly present for the Maldives, and the addresses by Tuvalu were characterized by the dominance of reality tests together with existential tests over time. The same holds true for environmental NGOs for which we found truth tests in only one plenary statement delivered at early climate summit in 2001. For Youth NGOs, existential tests played a dominant role over time, and none of the statements included in our sample contained a truth test.

Insert Figure 3

\section{Discussion}

As argued in our findings, the COPs constituted moments where different political actors voiced critique of the climate change policy process. Actors deploying truth tests tended to emphasize progress made with regards to established milestones and metrics whose legitimacy or meaning remained unquestioned. Those deploying reformist critique often emphasized the goals or principles of action, including the shared values of the United Nations or the institutionalized goals of the UNFCCC. Radical critique, however, brought up foundational questions of human life, the future, and the viability of sustainable society in conditions of climate change, 
contrasting these values and goals with lived experiences especially of marginal actors most immediately threatened by climate change.

By examining how different forms of critique are both expressed and contained from within institutionalized forms of expression, we contribute to discussions of institutional change and stability as a result of micro-level agency (e.g. Bitektine \& Haack, 2015; van Dijk et al, 2011), particularly in the context of organized events (Massa et al, 2016; Patriotta \& Hirsch, 2016; Schüßler et al, 2014). Specifically, our study of these forms of critique informs discussions of the microfoundations of institutions in that it both highlights how actors can use different rhetorical repertoires to create and engage in struggles for legitimacy to maintain or disrupt institutions (cf. Cloutier \& Langley, 2013), while at the same time hinting at the limits of such struggles in contexts where they are highly scripted, such as organized events. In principle, French Pragmatist Sociology provides many avenues for moving beyond the "paradox of embedded agency" towards a conceptualization of actors that competently dispute and contest institutions in situations of interaction and conflict (Cloutier \& Langley, 2013; DiazBone, 2013). Also, in principle, organized events can act as catalysts of change by facilitating such interactions and situations to occur (Lampel \& Meyer, 2008). Despite these two possibilities for institutional change, our study shows that more radical critique can be "contained" within the event in ways that may have diffused their efficacy. For instance, radical critique was systematically marked by highly emotional and subjective tropes and limited to non-state actors. They were concentrated in the Youth NGOs, where their radical content could be appreciated as engaging without posing a deep threat to the underling power structures of the conference. In this way, critique itself could be seen as a ritualized display, becoming "part of the script" and ultimately reinforcing of the sense of the event qua democratic forum.

Two broad questions can be taken from this idea of ritualized critique to better understand how organizational events underwrite institutional dynamics. The first involves the role of ritualization of action in events and its implications for the microfoundations of institutions. Organizational scholarship has highlighted the ambivalence of critique from within ritualized events (e.g. Toraldo et al, 2018; Islam, Zyphur \& Boje; 2008). While Boltanski's (2011) discussion of critique takes into account the progressive "embodiment" of critique in operational procedures, it does not consider the situated performance of the critical moment itself and its implications for how critique functions. Within the context of an organized event structured around speech performances, critique's dual nature - as ritualizd performance and as substantive argument - means that the precise functions of a critical act are not transparent. The language of radical change (along with the often dramatic emotional gestures accompanying it) is no longer a straightforward expression of meaning. Yet, words continue to matter substantively, and it would be premature to discount the substance of such critique. Thus, the question arises regarding the ways in which discursive argumentation within institutional contexts depends for its effects on specific histories and contexts of articulation.

The second question pertains more generally to the relation between ritualized critique and institutional work, particularly where critique is distributed unequally across actors with asymmetric power relations. On the one hand, and in line with research on institutional change, existential forms of critique usually come from marginal or peripheral actors, but these actors have little power to actually enforce and implement changes in institutions. On the other hand, critical theoretic debates have long held that "internal" critique is a more robust and effective vehicle for transformation than "external critique" (e.g. Sonnenschein, 2005; Honneth, 1991). The question thus remains, under what conditions can radical critique transform institutional orders from the inside, without becoming captured in the very order with which it engages to embed its critique? Such embeddedness of critique into dominant discursive forms highlights the question to what extent critical voices from the periphery can be worked into dominant 
institutional forms (Spivak, 1988) without further manifesting their marginal position through a clear ascription of roles and a "bracketing" of critique in certain moments and procedures.

In our work, by using using the differentiated notion of critique as tests, we contribute to emerging perspectives on the relations between French pragmatist sociology and institutional perspectives (e.g. Cloutier \& Langley, 2013; Brandl, Daudigeos, Edwards, \& PernkopfKonhäusner, 2014; Patriotta, Gond, \& Schultz, 2011). As noted by the editors of the current volume, the question of bridging micro and macro perspective is an ongoing challenge in institutional theory, and one central to pragmatist discussions. For instance, Boxenbaum (2014) stresses the pertinence of this work to understand embedded agency, while Bullinger (2014) notes how institutional logics can benefit from understanding pragrmatist conceptions of worth. By leveraging the notion of test to understand the dynamics of institutional critique, we are able to understand why marginal actors' critical moves are often both formally permitted in institutionalized procedures, yet ultimately ineffective. Contrary to other descriptions of discursive struggle in organized events (Hardy \& Maguire, 2010), in our setting, the articulation of critique in its ritualized form seemed less disruptive than its content would suggest. This pushes us to think further about how less institutionalized settings for critique and alternative policy processes could potentiate critique. In short, the possibilities for effective critique were bounded by the eventful nature of the phenomenon and, in particular, its ritualization. Institutional alternatives could include focusing negotiations on key carbon emitters (Victor, 2011) and avoiding the spectacular ritualization of critique, or conversely, broadening the conversation to include non-formatted expressions of radical critique from diverse actors. Both of these efforts could be complemented by a greater use of experimental spaces for institutional innovation (Cartel et al., 2018), though arguably transnational climate policy is not lacking innovative ideas, but rather their anchoring in political agendas. Given that such ideas require embodiment in institutions through tests, both as rules and regulations, and as shared visions of a common humanity, the credibility of such tests and the critique they sustain is of paramount importance. Displays of critique can be moving as institutional performances; their performance in moving institutions, however, remains to be seen.

\section{References}

Abdelnour, S., Hasselbladh, H., \& Kallinikos, J. (2017). Agency and institutions in Organization Studies. Organization Studies, 38(12), 1775-1792.

Anand, N., \& Watson, M. R. (2004). Tournament rituals in the evolution of fields: The case of the Grammy Awards. Academy of Management Journal, 47, 59-80.

Battilana, J., \& D'Aunno, T. (2009). Institutional work and the paradox of embedded agency. In T. Lawrence, R. Suddaby, \& B. Leca (eds.). Institutional Work: Actors and Agency in Institutional Studies of Organizations (pp. 31-58). Cambridge, UK: Cambridge University Press.

Bitektine, A., \& Haack, P. (2015). The "macro" and the "micro" of legitimacy: Toward a multilevel theory of the legitimacy process. Academy of Management Review, 40(1), 4975.

Blokker, P. (2014). 'The Political' in the 'Pragmatic Sociology of Critique': Reading Boltanski with Lefort and Castoriadis. In S. Susen, \& B. S. Turner (eds.) The Spirit of Luc Boltanski: Essays on the 'Pragmatic Sociology of Critique' (pp. 369-390). New York: Anthem Press.

Boltanski, L. (2011). On Critique: A Sociology of Emancipation. Cambridge: Polity.

Boltanski, L. and Thévenot, L. (2006). On Justification: Economies of Worth, translated by Porter, C. Princeton, NJ: Princeton University Press. 
Boxenbaum, E. (2014). Toward a situated stance in organizational institutionalism: Contributions from French pragmatist sociology theory. Journal of Management Inquiry, 23(3), 319-323.

Boltanski L., \& Chiapello, E. (2005). The New Spirit of Capitalism. New York: Verso.

Brandl, J., Daudigeos, T., Edwards, T., \& Pernkopf-Konhäusner, K. (2014). Why French pragmatism matters to organizational institutionalism. Journal of Management Inquiry, 23(3), 314-318.

Bullinger, B. (2014) Family affairs: Drawing on family logic and familiar regime of engagement to contrast "close-up" views of individuals in conventionalist and institutionalist reasoning. Journal of Management Inquiry, 23, 328-332.

Cartel, M., Boxenbaum, E., \& Aggeri, F. (2018). Just for fun! How experimental spaces stimulate innovation in institutionalized fields. Organization Studies, 0170840617736937.

Cloutier, C., \& Langley, A. (2013). The logic of institutional logics: Insights from French Pragmatist Sociology. Journal of Management Inquiry, 22, 360-380.

Diaz-Bone, R. (2014). Methodological positionings and perspectives: Comparing economics of convention with the institutional logics approach. Journal of Management Inquiry, 23(3), 324-327.

Dansou, K., \& Langley, A. (2012). Institutional work and the notion of test.M@n@gement, 15, 503-527.

Durkheim, E. (1961). The Elementary Forms of Religious Life (J. W. Swain, Trans.). New York:

Collier. (Original work published 1915)

Hardy, C., \& Maguire, S (2010). Discourse, field-configuring events, and change in organizations and institutional fields: Narratives of DDT and the Stockholm Convention. Academy of Management Journal, 53(6), 1365-1392.

Hodgson, G. M. (2007). Institutions and Individuals: Interaction and Evolution. Organization Studies, 28(1), 95-116.

Honneth, A. (1991) The Critique of Power, trans. Kenneth Baynes. Cambridge, MA: MIT Press.

Islam, G., \& Keliher, M. (2017). Leading through ritual: Ceremony and emperorship in early modern China. Leadership, onlinefirst. http://doi.org/10.1177/1742715016685917

Islam, G (2015). Organizational ritual: Rupture, repetition, and the institutional event. In H. Wilmott, R. Mir \& M. Greenwood (eds.). Handbook of Philosophy and Organization (pp. 542-549). London: Routledge.

Islam. G., Zyphur, M.J., Boje, D. (2008). Carnival and spectacle in Krewe de Vieux and the Mystic Krewe of Spermes: The mingling of organization and celebration.

Organization Studies, 29,1565-1589.

Koschmann, M. A., \& McDonald, J. (2015). Organizational rituals, communication, and the question of agency. Management Communication Quarterly, 29(2), 229-256.

Lampel, J., \& Meyer, A. (2008). Field-configuring events as structuring mechanisms: How conferences, ceremonies, and trade shows constitute new technologies, Industries, and Markets. Journal of Management Studies, 45(6), 1025-1035.

Lawrence, T. B., \& Suddaby, R. (2006). Institutions and institutional work. In S. R. Clegg, C. Hardy, T. B. Lawrence \& W. R. Nord (eds.), The Sage Handbook of Organizational Studies (2nd ed., pp. 215-254). London: Sage.

Levy, D. L., \& Spicer, A. (2013). Contested imaginaries and the cultural political economy of climate change. Organization, 20(5), 659-678.

Lok, J. (2017). Why (and how) institutional theory can be critical: Addressing the challenge to institutional theory's critical turn. Journal of Management Inquiry, doi 1056492617732832. 
Massa, F., Helms, W. S., Voronov, M., \& Wang, L. (2016). Emotions uncorked: Inspiring evangelism for the emerging practice of cool climate winemaking in Ontario. Academy of Management Journal, 60(2), 461-499.

Moellendorf, D. (2016). Taking UNFCCC norms seriously. Climate justice in a non-ideal world, in: Clare Heyward, Dominic Roser (eds) : Climate Justice in a Non-Ideal World. Oxford, OUP : 104-21.

Patriotta, G., \& Hirsch, P. M. (2016). Mainstreaming innovation in art worlds: Cooperative links, conventions and amphibious artists. Organization Studies, 37(6), 867-887.

Patriotta, G., Gond, J-P., \& Schultz, F. (2011) Maintaining legitimacy: Controversies, orders of worth, and public justifications. Journal of Management Studies, 48(8), 1804-1836.

Powell, W. W., \& Rerup, C. (2017). Opening the black box: The microfoundations of instititutions. In: R. Greenwood, C. Oliver, T.B. Lawrence, \& R.E. Meyer (eds.). The Sage Handbook of Organizational Institutionalism. Thousand Oaks: Sage.

Puett, M. (2006). Innovation as ritualization: The fractured cosmology of early China. Cardozo Law Review, 28: 23-36.

Rojek, C. (2013). Event Power: How Global Events Manage and Manipulate. Sage.

Schüßler, E., Grabher, G., \& Müller-Seitz, G. (2015). Field-configuring events: Arenas for innovation and learning? Industry and Innovation, 22(3), 165-172.

Schüßler, E., Rüling, C., \& Wittneben, B. (2014). On melting summits: The limitations of fieldconfiguring events as catalysts of change in transnational climate policy, Academy of Management Journal, 57, 140-171.

Sonenshein, S. (2005). Business ethics and internal social criticism. Business Ethics Quarterly, 15(3), 475-498.

Spivak, G. C. (1988). Can the subaltern speak? In C. Nelson \& L. Grossberg (Eds.), Marxism and the interpretation of culture: 271-313. Urbana: University of Illinois Press.

Stones, R. (2014). Strengths and limitations of Luc Boltanski's 'On Critique'. In S. Susen, \& B. S. Turner (eds.) The Spirit of Luc Boltanski: Essays on the 'Pragmatic Sociology of Critique' (pp. 211-234). New York: Anthem Press.

Taupin, B. (2012). The more things change... Institutional maintenance as justification work in the credit rating industry. $M @ n @ g e m e n t, 15(5), 528-562$.

Toraldo, M.L., Islam, G. \& Mangia. G. (2018) Serving time: Volunteer work, liminality and the uses of meaningfulness at music festivals. Journal of Management Studies, onlinefirst.

van Dijk, S., Berends, H., Jelinek, M., Romme, a. G. L., \& Weggeman, M. (2011). Microinstitutional affordances and strategies of radical innovation. Organization Studies, 32(11), 1485-1513.

van Gennep, A. (1960) The Rites of Passage. London: Routledge \& Kegan Paul. Original work published in 1908.

Victor, D. G. (2011). Global warming gridlock: creating more effective strategies for protecting the planet. Cambridge University Press.

Zilber, T. B. 2011. Institutional multiplicity in practice: A tale of two high-tech conferences in Israel. Organization Science, 22(6), 1539-1559. 


\section{FIGURES}

FIGURE 1

Critical tests as forms of critique (own depiction based on Boltanski, 2011)

"Reality"

(fragile, oriented towards the preservation of order)

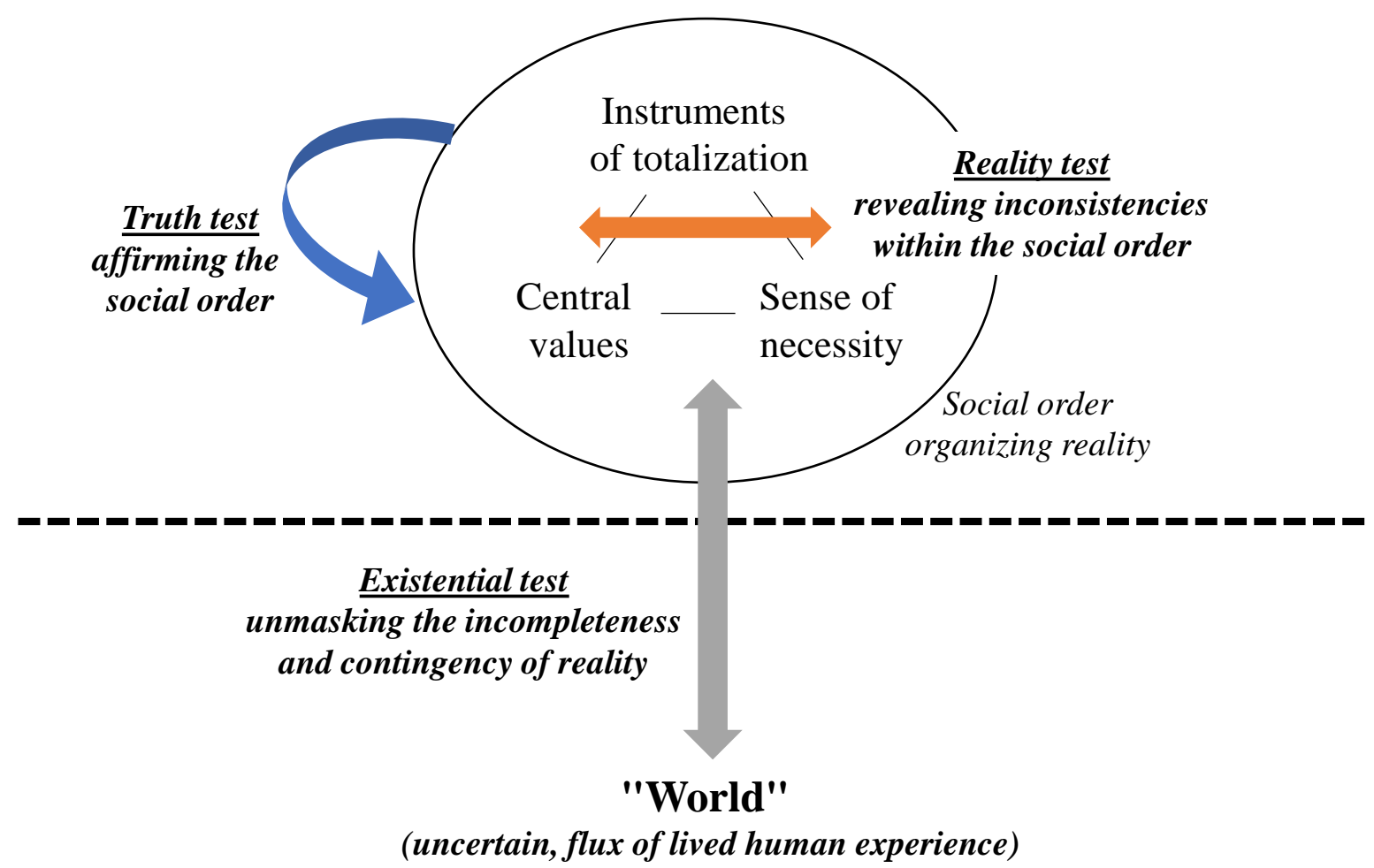


FIGURE 2

Relative Weight of Test Types in UNFCCC COP Plenary Addresses (1997-2015)

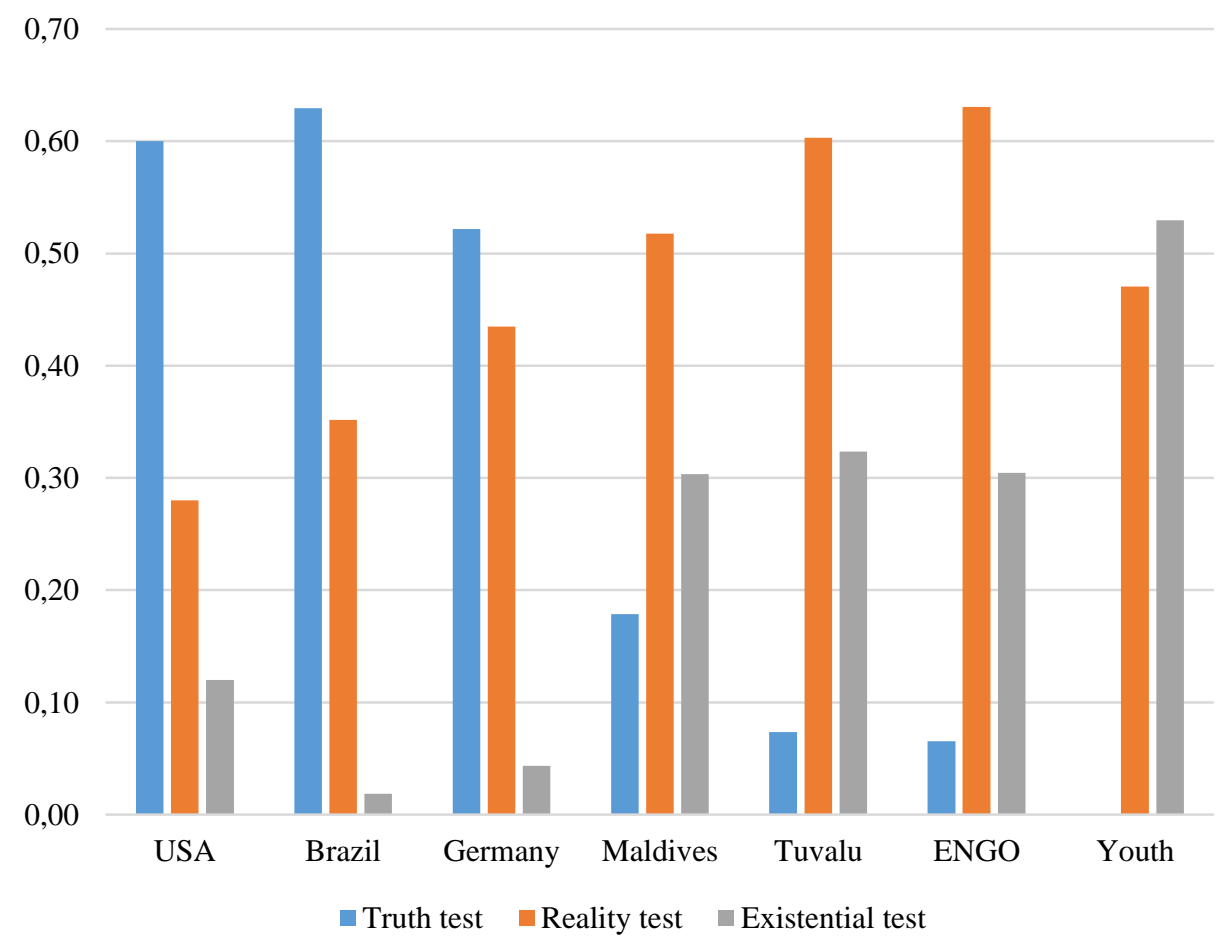

NB: Values represent the share of text passages coded as test for each test type in COP plenary addresses in 1997, 2001, 2006, 2008, 2009, 2010, 2011, 2012, 2013, and 2015. 


\section{FIGURE 3}

\section{Relative Weight of Test Types Over Time (1997-2015)}
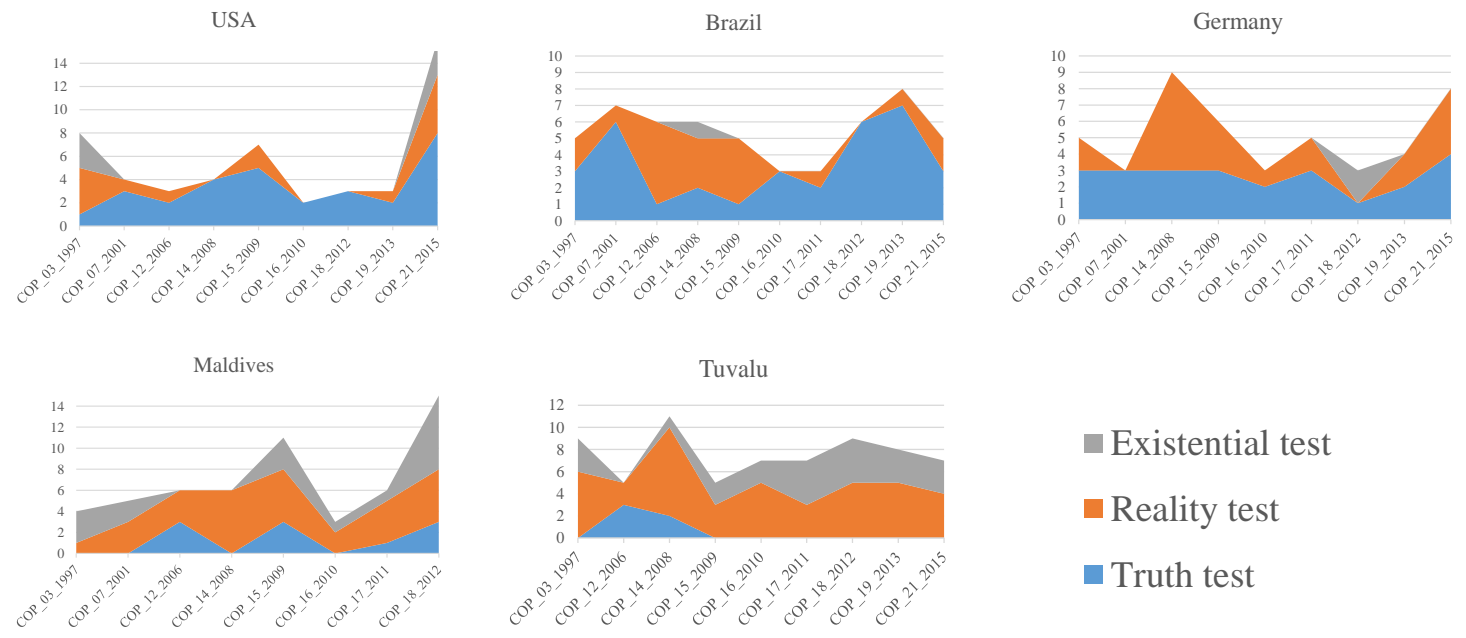

$$
\begin{aligned}
& \text { Existential test } \\
& \text { Reality test } \\
& \square \text { Truth test }
\end{aligned}
$$
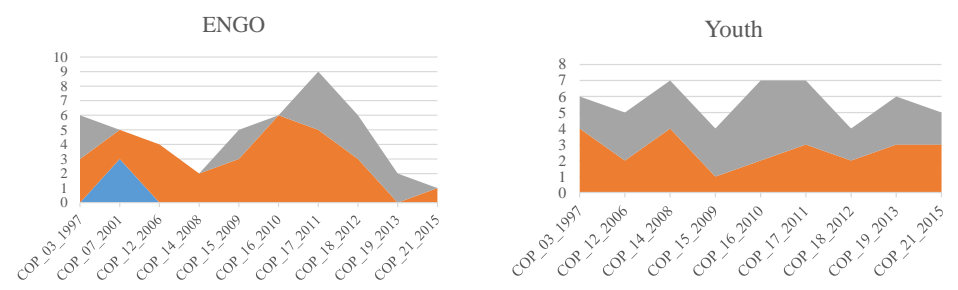

NB: Values represent the cumulated number of occurrences of codes for each test type in COP pleanry addresses in 1997, 2001, 2006, 2008, 2009, 2010, 2011, 2012, 2013, and 2015. Missing years correspond to COPs without plenary statement by the respective actor. 
TABLES

TABLE 1

\section{Illustrative Quotes for Test Types in UNFCCC COP Plenary Addresses}

\begin{tabular}{|c|c|}
\hline Type of Test & Illustrative quotes \\
\hline Truth test & $\begin{array}{l}\text { Since } 2001 \text { the United States has invested } 29 \text { billion in climate, science and technology investments to } \\
\text { make our future actions strategic and sustainable. We are also engaging nations around the world to } \\
\text { build innovative results oriented approaches to contribute to the convention. Since } 2002 \text { we have } \\
\text { launched seven international partnerships to advance the development and deployment of clean } \\
\text { technologies. These partnerships are designed to advance key technologies as hydrogen, carbon } \\
\text { capture and nuclear fission as well as reducing methane emissions. (USA, COP12, 2006) } \\
\text { We will ... continue to work towards the correct implementation of the clean development mechanism } \\
\text { which holds the promise of becoming an effective tool for involvement of developing countries in } \\
\text { the global effort. (Brazil, COP07, 2001) } \\
\text { [W]e have set ourselves high ambitions towards low carbon development. Through our efforts, we } \\
\text { hope to showcase our selected islands as role models to the rest of the nations in the world and } \\
\text { demonstrate not only our leadership in mitigation but also our ability to enhance our energy security } \\
\text { and contribute to our adaptation. We have established several protected areas and species, and have } \\
\text { declared to make the whole country a biosphere reserve within the next five years. (Maldives, } \\
\text { COP18, 2012) }\end{array}$ \\
\hline Reality test & $\begin{array}{l}\text { [W]e firmly believe that various measures and discounting strategies proposed at this conference ... } \\
\text { will not adequately address the immediate need to reduce emissions and curb climate change } \\
\text { impacts... We agree that advanced developing countries' emissions are set to contribute to the } \\
\text { global problem of climate change in the very near future. However, we think it is important that } \\
\text { Annex One countries should agree to legally binding commitments now and that advanced } \\
\text { developing countries follow on emission reduction thereafter. (Tuvalu, COP03, 1997) } \\
\text { [O]ur efforts to combat climate change are still inadequate. In fact some of the goals we thought we } \\
\text { had achieved are now under threat. Our negotiations are by far not progressing fast enough. We are } \\
\text { not making any progress on crucial issues. Despite of clear knowledge of what is necessary, we are } \\
\text { not even able to decide on the range of necessary midterm reduction by developed countries, let } \\
\text { alone on urgently needed financing structures for adaptation and technology transfer. (Germany, } \\
\text { COP14, 2008) } \\
\text { A fighting chance for closing the ambition gap mostly rests with the developed countries and requires } \\
\text { revisiting INDCs by } 2018 \text { at the latest. In many countries, further ambition needs to be enabled. The } \\
\text { Paris agreement should stipulate that collective targets for the provision of finance should be set and } \\
\text { updated in } 5 \text { year cycles or separate mitigation adaptation targets. Climate impacts and irreversible } \\
\text { losses must be addressed by a global goal on adaptation ... A transformative Paris agreement needs } \\
\text { to be binding and dynamic. (ENGO, COP21, 2015) }\end{array}$ \\
\hline Existential test & $\begin{array}{l}\text { We are not in a position to change the course of events in the world. But what you do or do not do here } \\
\text { will greatly influence the fate of my people. ... Indeed the fate of the entire world is at stake for } \\
\text { climate change is the most pervasive threat that looms before us. ... This is a plea of a small state and } \\
\text { endangered people. ... Ultimately ours is not a plea merely to save ourselves, it is one to save the } \\
\text { whole world. Our destiny cannot be separated from the rest. If we miss this vital opportunity, the } \\
\text { future of the mankind may be unthinkable. (Maldives, COP 03, 1997) } \\
\text { We cannot let the fossil fuel lobby continue to manipulate this process.... As a woman from the United } \\
\text { States of America, I cannot accept this. I cannot accept that the world's largest polluter proposes a } \\
\text { target that in essence allows for increase of emissions. I cannot accept that they refuse to take } \\
\text { responsibility for their actions which have immense impacts on others around the world. And I } \\
\text { cannot accept that the burden of acting is being shifted to my children and my grandchildren. There } \\
\text { is a moral imperative to act. ... The world is watching. (ENGO, COP03, 1997) } \\
\text { We cannot be asked to compromise when our survival as a nation is at stake. Every concession we } \\
\text { make is a physical concession rather than just a political one, because we concede our land and } \\
\text { livelihoods to the worsening climate impacts. (Maldives, COP17, 2011) } \\
\text { Tuvalu's future at current warming is already bleak, any further temperature increase will spell the } \\
\text { total demise of Tuvalu. No leader around this room carries such a level of worry and responsibility. } \\
\text { Just imagine you are in my shoes, what would you do? We want to be assured that our children and } \\
\text { our grandchildren have a future. (Tuvalu, COP21, 2015) }\end{array}$ \\
\hline
\end{tabular}

